\title{
Grounding E-Government in Vietnam: From Antecedents to Responsive Government Services
}

\author{
Tuyen Thanh Nguyen and Don Schauder \\ Monash University, Australia
}

\begin{abstract}
The paper concerns the antecedents or preconditions for the successful development of e-government in Vietnam. The main antecedent issue under consideration is the readiness of the population to access and use networked ICTS, the prime communication medium of e-government. The paper reports the results of in-depth interviews with 38 citizens in various regions of the country. Its purpose is primarily to examine the capacity of citizens to become effective users of e-government services in terms of their access to, and capacity to use, ICTs. Its subsidiary purpose, in the light of these user-centric considerations, is to offer some thoughts on how government in Vietnam might position itself better to provide effective egovernment services. In essence the paper attempts to shed light on the following questions: How ready is the population to make use of e-government services if these were provided? How ready is government to provide a full range of e-government services to this population? At present only 16 million out of Vietnam's more than 85 million people are ICT/Internet users. If e-government service delivery is to be effective, clearly a much greater proportion of the population needs to become users. The paper looks at case studies of users and non-users, as well as background data from a variety of Vietnamese and international sources, in order to frame initial suggestions about how barriers to wider internet use can be overcome, and how services to current and future users could be made more effective.
\end{abstract}

\section{Key words}

E-government, electronic government, ICT users, ICT non-users, Vietnam, Internet

\section{Introduction and Aims}

This paper was developed from a presentation to the 'Vietnam E-Government Symposium 2006 - The Bridge for Government, Business and Citizens'. That presentation and this paper form part of a greater project on the role of ICTs in the development of Vietnam as a sustainable knowledge economy.

The paper concerns the antecedents or preconditions for the successful development of e-government in Vietnam. The main antecedent issue under consideration is the readiness of the population to access and use networked ICTs, the prime communication medium of e-government.

The paper reports the results of in-depth interviews with 38 citizens in various regions of the country. Its purpose is primarily to examine the readiness of citizens to become effective users of e-government

Copyright (C) 2007 Victoria University. This document has been published as part of the Journal of Business Systems, Governance and Ethics in both online and print formats. Educational and non-profit institutions are granted a nonexclusive licence to utilise this document in whole or in part for personal or classroom use without fee, provided that correct attribution and citation are made and this copyright statement is reproduced. Any other usage is prohibited without the express permission of the services in terms of their access to, and capacity to use, ICTs. Its subsidiary purpose, in the light of these user-centric considerations, is to offer some thoughts on how government in Vietnam might position itself better to provide effective egovernment services. In essence the paper attempts to shed light on the following questions: How ready is the population to 
make use of e-government services if these were provided? How ready is government to provide a full range of e-government services to this population?

The assumption is made in this study that the aim of e-government is to improve the responsiveness of government to the needs of people, or in other words (to borrow from Abraham Lincoln) contribute to the reality of government of, by and for the Vietnamese people, and that e-government can play a role in this by improving communication between government and people (Nguyen 2001). At present only 16 million out of Vietnam's more than 85 million people are internet users. If e-government service delivery is to be effective, clearly a much greater proportion of the population needs to become Internet users. This paper looks at case studies of users and non-users in order to frame initial suggestions about how barriers to wider internet use can be overcome, and how services to current and future users could be made more effective.

\section{The Concept of E-government and Factors Contributing to its Success}

The term 'electronic government' or 'e-government' appeared about a decade ago and there is no commonly accepted definition (Bhatnagar 2004). Oliver and Sanders saw e-government as "the migration of government information and services to an on-line delivery mode" (Oliver and Sanders 2004). As with the concept of 'e-commerce', the scope of e-government covers the interaction between government and citizens (G2C), government and business enterprises (G2B), and inter-agency dealing (G2G).

In this article we shall use the broad definition of e-government provided by Marche and McNiven: "the provision of routine government information and transactions using electronic means, most notably those using Internet technology, whether delivery at home, at work, or through public kiosks" (Marche and McNiven 2003).

It is an underlying assumption in this paper that Internet technologies and specifically e-government should have as their main purpose the improvement of the ways in which government serves its citizens and the ways in which citizens interact with public institutions.

Martin and Byrne stated their philosophy of e-government in even stronger terms:

It seems clear that for e-government to be anything more than automated service provision it needs to reach far beyond the conduct of routine government business to embrace social, economic and political change (Martin and Byrne 2003).

Marche and McNiven (2003) stressed that successful e-government programs should not only be based on the perceived efficiency gains for government itself, but rather on the satisfaction of consumers. Kolsaker and Lee-Kelley (2006) criticised the UK's 'techno-centric model' which they argued 'fails to engage citizens as anticipated, underplays the importance of Knowledge Management (KM) and clashes with the traditional values of public service'.

Dada (2006) mentioned factors which would be important from the perspective of the suppliers of egovernment: the capacity for significant organisational change, the development of leadership skills, a grasp of the distinction between 'hard' (technological factors) versus 'soft' (human factors), and understanding of the differences in catering for the private and public sectors, and for citizens in developed and developing countries.

From the perspective of citizens' needs (the 'demand side' in e-commerce terms), Margetts and Dunleavy (2002) stressed the vital role of factors such as the impact on citizens of transaction costs, an understanding of cultural barriers, for example social exclusion caused by the problem of unequal access to the Internet, citizens' expectations of government services and their degrees of acceptance of technological innovations, and possible mismatches between governmental and social uses of the Internet'. 
Recently, Intel joined with the Government for the Third Millenium Foundation (Gov3) to publish a white paper on global best practice in delivering public services. This paper expressed similar ideas in stressing the need for a 'citizen-centric' service model, which:

treats citizens and businesses like customers. Citizen-centricity is about turning the focus of government around - looking at the world though the other end of the telescope, so that the needs of the citizen and businesses come first, rather than operational or other imperatives inside the government (Intel and Gov3 2006).

\section{The Context of ICT in Vietnam}

At the national level, government in Vietnam consists of the dual structures of the Communist Party and the National Government. The country is organized at local government level into 64 provinces. The provinces are divided into 588 districts, which are further subdivided into 9069 communes (General Statistics Office of Vietnam 2006).

According to the CIA World Factbook (2007) the area of Vietnam is $329,560 \mathrm{sq} \mathrm{km}$. Total population is 85.26 million (July 2007 est.) with a median age of 26.4 years, comprising $26.3 \%$ of $0-14$ years, $67.9 \%$ of $15-64$ years, and only $5.8 \%$ of 65 years and over (Central Intelligence Agency 2007).

Approximately 60 million live in a rural setting with farming as the main occupation (General Statistics Office of Vietnam 2006).

Vietnam has undertaken a far-reaching process of economic reform known as 'Doimoi' since 1986. The Government of Vietnam committed to increased economic liberalization and enacted structural reforms needed to modernize the economy and to produce more competitive, export-driven industries. Achievements of Doimoi have been spectacular. According to a World Bank (2003) report, the progress made in Vietnam in alleviating poverty has been one of the greatest success stories in world economic development in recent years. Poverty rates measured at international levels have halved from $58 \%$ in 1992 to $37 \%$ in 1997 and 29\% in 2002 (World Bank 2003) and further down to $24.1 \%$ in 2004 (ADB 2005). Together with poverty reduction, the country had very successful economic growth since 1990 with around 8\% annual GDP growth from 1990 to 1997, 5.5\% from 1998 to 2000, over 7\% from 2002 to 2005 and $8.4 \%$ in 2006 , making it the world's second-fastest growing economy. The country also achieved a high rate of increase in exports, from US\$9.1 billion in 2001 to US\$16.5 billion in 2002 or over $12 \%$ a year (Dapice and Fellow 2003). In 2005, nominal GDP and per capita GDP were US\$52.8 billion and US\$636, respectively (Baker, Tumbarello and Ahmed 2006).

At present (June 2007) about sixteen million people are users of the Internet, while just under 70 million others conduct their lives without the use of computers (Vietnam Internet Center 2007). The growth of Internet usage in Vietnam over the 5 year period to 2005 is shown in Figure 1. The leap from 7.5 million users in 2005 to 16 million in 2007 underlines a trend of rapid growth.

Figure 1 - Internet Development in Vietnam 


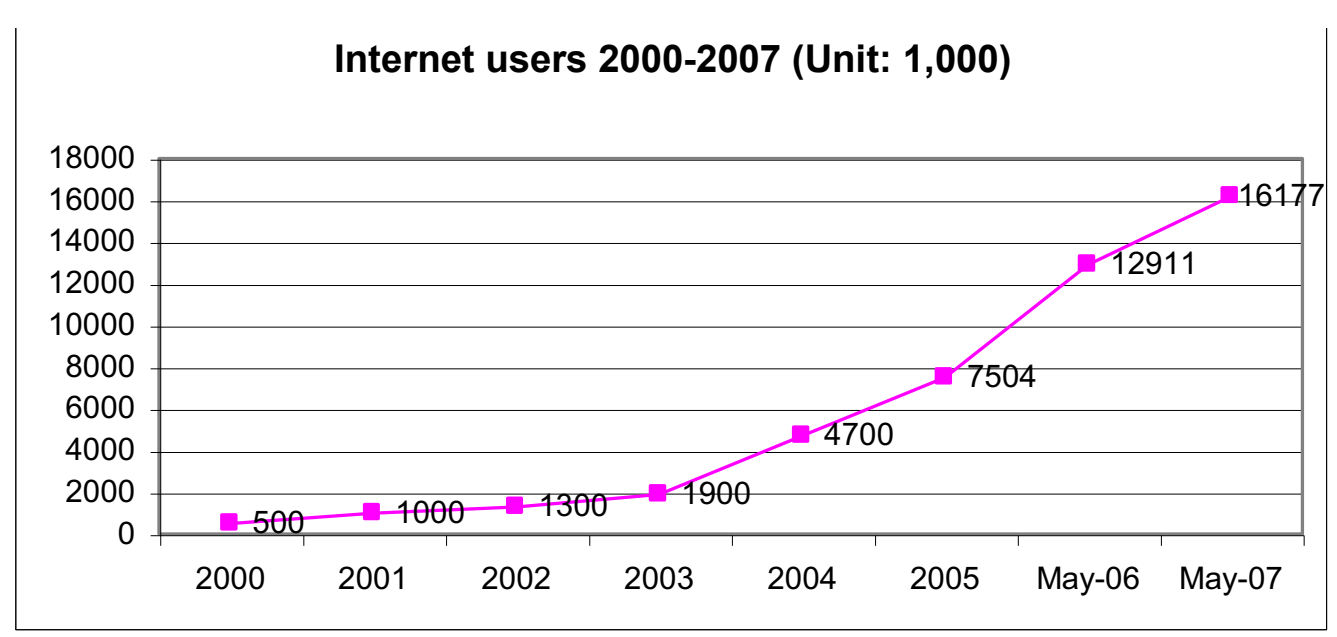

Source of data 2000-2004: Hochiminh Computer Association (2006); and 2005-2007 from Vietnam Internet Center (2007)

Further insight regarding ICT/Internet usage is provided by the statistics assembled in Table 1 below. This Table shows that despite the vigorous growth in the absolute number of users, the percentage of ICT usership - including telephony - in the population as a whole is still very low.

Table 1 - Vietnam ICT use statistics

\begin{tabular}{|l|l|l|l|l|}
\hline $\begin{array}{c}\text { Telephone } \\
\text { subscribers per 100 } \\
\text { inhabitants }\end{array}$ & $\begin{array}{c}\text { Internet } \\
\text { users per } \\
\text { 100 } \\
\text { inhabitants }\end{array}$ & $\begin{array}{l}\text { PCs per 100 } \\
\text { inhabitants }\end{array}$ & \multicolumn{2}{|c|}{ Global e-readiness rankings } \\
\hline $29.42^{*}$ & $12.72 *$ & $1.26^{*}$ & $61 / 65^{* *}$ & $68 / 104^{* * *}$ \\
\hline $\begin{array}{l}\text { Sources: } \\
*\end{array} \quad \begin{array}{l}\text { International Telecommunications Union (2005) (ITU 2006) } \\
* *\end{array} \quad \begin{array}{l}\text { Economist Intelligence Unit (2005). Ranked form 65 countries (EIU 2006) } \\
* * *\end{array} \quad$ Global Information Technology Report (2005). Ranked out of 104 countries (Dutta and Jain 2004) \\
\hline
\end{tabular}

Amongst small enterprises in Vietnam the diffusion of ICTs and the Internet in particular has been slow. In a case study in 2005 of nine traditional villages focusing on small enterprises and e-commerce, Tran identified the following difficulties: unreliable technological infrastructure, lack of legal infrastructure, blocking of Internet access due to security concerns, and high cost of Internet connectivity (Tran 2005). However, despite the infrastructural constraints and difficult conditions, a number of small enterprises are engaging in e-business.

E-government cannot be achieved without the availability of telecommunications infrastructure. With the increase in use shown in Figure 1 and Table 1 has come an 'explosion' in the development of the Vietnamese ICT sector since the turn of the millennium. According to statistics presented by the World Bank (World Bank and WITSA 2004), Vietnam's investment in ICT infrastructure as a percentage of GDP was of a similar order to that of larger economies in the region: Vietnam spent $7.3 \%$ of GDP, while South Korea spent 6.7\%; Japan 7.4\%; and Hong Kong 8.4\%. Clearly the absolute figure spent in Vietnam was much lower than that of these countries, given the differentials in GDP terms. The 2006 estimated per capita GDP (PPP - purchasing power parity, per capita) comparison expressed in U.S. dollars is Vietnam: 3,100; South Korea: 24,500; Japan: 33,100; Hong Kong: 37,300 (CIA World Factbook 2007). Nevertheless the level of commitment being made in percentage terms sets a good base for long term development.

Chowdbury and Cuong et al (2002) reported that the Vietnamese government was enthusiastic in encouraging e-commerce and e-government projects, introducing ICT strategies and ICT parks to attract foreign companies. Policy makers have also been keen to foster B2B e-commerce to promote 
export industries, however both $\mathrm{B} 2 \mathrm{~B}$ and $\mathrm{B} 2 \mathrm{C}$ e-commerce have been described as negligible. These authors identified some challenges to ICT expansion in Vietnam, namely: lack of sufficient competition in the ICT sector; high piracy rates; and a shortage of ICT skilled labor.

The first attempt to build e-government in Vietnam was the '112 Project' on computerization of state administration in the framework of the Public Administration Reform (PAR), starting in 1999. In parallel with the 112 Project which focused more on internal administration, almost all ministries and national departments and all 64 provincial governments developed their websites which were linked to the government portal www.chinhphu.vn/portal to provide information and limited services to business and individuals. In 2007, the government discontinued the 112 project to prepare a more comprehensive e-government program (Nguyen 2007).

Furthermore, several initiatives are underway to improve the national environment for 'e-facilitated' trade and to provide support and encouragement to businesses taking advantage of this (Gammack et al, 2004).

Kaufmann, Kraay et al (2006) summarized and interpreted the findings of a World Bank report "Governance Matters V: Governance Indicators for 1996-2005" which covered 213 countries and territories. The report assessed six dimensions of governance: voice and accountability; political stability and absence of violence; government effectiveness; regulatory quality; rule of law; and control of corruption in the political regime. In this report, the political regime in Vietnam was seen as stable, but the other five elements received very low scores compared with other countries. Moreover little improvement was discerned in the ten year period. The analysis suggested that improvement was needed in the capacity of government to manage its resources effectively and to formulate and implement sound policies. Such improvements are required for greater responsiveness to the needs of citizens, both in the community and business sectors, especially at a time when Vietnam is integrating into the global economy and joining the World Trade Organisation (WTO) in January 2007.

The benefits of Vietnamese online services were still very limited. According to Pham, less than $50 \%$ of the provincial websites provided information related to investment, licensing, land permits, customer and taxation. Only two out of 49 websites provided on-line services about the matters (Pham 2005). For instance, NBIN, an automation of the business registration process, did not allow any registration to be carried out online. That static website simply provided information and application forms and people still had to meet government staff to register their business (Vu and Jones 2006). Furthermore, little attention had been given to identify the needs and obstacles of the people in relation to e-government. Egovernment projects basically focused on internal administration - G2G affairs rather than G2C and G2B relationships. Vu and Jones (2006) argued that:

\section{E-Government initiatives have been far too focused on modernization and the purchase of hardware for government agencies... All initiatives (Project 112 and PAR initiatives) are supply side focused with little thought to the actual needs of users, business and citizens, and how these needs can best be met...}

They thus commented that 'the service needs of citizens and businesses be addressed and e-government initiatives and PAR meet these needs rather than taking a supply side approach to projects' (Vu and Jones 2006). Understanding of information on customers' needs together with technological and social obstacles and weaknesses in relation to online acceptance could help to reduce failures, extensive wastage of investment, and damage to credibility and reputation for future e-government projects.

\section{Methodology: a Case Based Approach}

The style of the research reported in this paper is mainly ethnographic and qualitative. In-depth insight, rather than statistical generalization, is the key outcome sought. The methodology seeks to triangulate case data with large data sets (where available) in order to establish strong inputs to policy development. 
The first author conducted 38 interviews in the Vietnamese language from January to April 2006. The interviewees were both ICT users (people who currently use computers) and ICT non-users, in order to identify and explore factors associated with adoption and non-adoption of ICTs. The study's sampling approach is described later. For the non-users, the following open-ended issues (among others) were investigated. What are major problems they encountered? What are major channels of information through which they acquire new information and knowledge to solve problems? What are barriers that prevent them from using ICTs? For the users, the key open-ended questions were as follows. For what purposes do they use ICTs? What are difficulties that they are experiencing and how do they deal with these? Does the usage of ICTs help them in their work and life?

An explanatory statement and a letter of consent were provided to let the interviewees know about the purpose and the method of the interview, and its compliance with ethical protocols, and to elicit their agreement to participate. If they agreed, the conversation started and was recorded. If any interviewee requested to be anonymous a code was used on their interview documentation. Otherwise, their names with the date of interview and a brief description were recorded. In this paper interviewees are referenced by their code number and their date of interview (e.g. I22, Feb 20, 2006).

As the Vietnamese language was used in the study to facilitate smooth conversation it was difficult to use automated qualitative analysis tools such as NVivo on the transcripts. Instead manual grouping of content was undertaken, and Excel spreadsheets were used to summarize data and discern patterns.

The sampling technique used for selecting the cases was purposive sampling, a non-probability sampling approach "used when the investigator is interested only in obtaining a sufficient number of elements to satisfy research objectives. The resulting sample is ... 'balanced' on a range of variables, for example sex, age, education, income, location (or place of abode) ..." (Williamson 2002). In other words, the sample is representative, but representativeness is not achieved through random selection as in a probability sample, but through criteria-based selection of the individuals to be included in the sample. Representativeness means that the subset under study should manifest, in an unbiased way, selected characteristics of the superset, that are seen to be important to the research. The practical success of such an approach to sampling is daily demonstrated in the business world, for example in focus group work undertaken by marketing professionals for product and service development.

A knowledgeable local guide was identified to help identify 16 non-users to interview. Agriculture still accounts for $20 \%$ of GDP (despite its recent decline in proportion to the national economy). Rural villages and hamlets house $74.1 \%$ of the whole population (Khổng 2002). Therefore care was taken to include rural, farm based interviewees who were interviewed at their homes.

For the users, 20 interviewees were chosen in Internet cafes or in their working places from North to South of Vietnam. In Internet cafes, the interviewer and his assistant walked in and selected one or two persons at each site. In addition, they also selected interviewees from a private shop, a university, a research unit and two governmental agencies. About $10 \%$ of people who were approached refused to be interviewed either because they were busy, or were anxious about disclosure. These were replaced with similar cases from the same categories.

\section{Characteristics of the Sample}

The cases included in the sample were 22 users and 16 non-users. For non-users an equal number of males and females were selected, but for users males predominated, reflecting the macro picture presented in the large statistical reports available. Among the users, 17 lived in cities and five in communes. Of the 16 non-users, five were in suburbs, four in agricultural villages, four in villages that were changing into towns and three were in the process of moving from the countryside to cities. By region, 28 lived in the North, one in the Centre and seven in the South of Vietnam. The composition of the sample is summarized in Table 2 below. 
Table 2 - Composition of Purposive Sample

$\begin{array}{lccc}\text { Gender } & \text { ICT/Internet Users } & \text { ICT/Internet Non-users } & \text { Totals } \\ \text { Male } & 14 & 8 & 22 \\ \text { Female } & 8 & 8 & 16 \\ \text { Location } & 5 & 8 & 13 \\ \text { Rural } & 17 & 8 & 25 \\ \text { Urban } & & & \\ \text { Age group of non-users } & & 3 & \\ 20-29 & & 3 & \\ 30-39 & & 4 & \\ 40-49 & & 3 & \\ 50-59 & & & \\ 60+ & & & \\ \text { Age group of users } & & & \\ 10-14 & & & \\ 15-19 & 1 & & \\ 20-24 & 6 & & \\ 25-29 & 7 & & \\ 30-34 & 6 & & \\ 35+ & 2 & & \\ & 0 & & \end{array}$

\section{Age}

Although no large scale statistical survey evidence was available regarding the relative ages of users and non-users, the purposive sample for users included more younger people than older to reflect both the overall youthful demographic of Vietnam and an assumption that usage is higher in the younger age groups. For non-users the interviewees were spread more or less evenly across age groups. It should be noted, however, that no non-users below the age of 20 were included, and it would be desirable to undertake follow-up study of non-users in this age bracket.

\section{Income}

Monthly income of non-users in the sample varied widely from VND 100,000 to $4,000,000$. The average income of a northern/central farmer and a student was much lower than that of other jobs (VND400,000 and 1,237,500, respectively). Other non-users had an income comparable to that of a user. It would be necessary to remark that 1 ) farmers were more economically self-reliant and their incomes, such as rice or maize, were often not accounted in monetary terms; 2) in 2006, US\$1 was VND 15,983 at the official exchange rate, yet was about 2,826VND in purchasing power parity (Central Intelligence Agency 2007). Thus, a farmer's actual income, if exchanged into money, could be higher. For the reader's reference, $1 \mathrm{~kg}$ of rice costs about VND 5,000 and a student's lunch costs from VND 5,000.

Users in the sample, excluding students, had an income varying from VND 600,000 to 3 million per month with a mean of VND 1,216,000. A student got a monthly allowance of about VND 544,000 on average. Rural users spent much less in total, but a relatively high proportion of their income. For instance, I22 (Feb 20, 2006) a rural high school student, paid VND 100,000 monthly, one third of his allowance, for the Internet - a considerable amount equivalent to his monthly rice budget.

\section{Education}

Categories commonly used to describe formal educational levels in Vietnam are primary, secondary, high school, vocational and higher training and 'other' - and these categories were used in the study. Among the non-user group in the sample, farmers had lower education (from primary to secondary 
levels) than the other occupations (from vocational training to higher education). Six users were university students and seven hold bachelor's degrees or above.

There were non-users who attained only primary education but there existed also ICT illiterates among high literates. Several non-users had attained high school graduation or bachelor degrees, or were university students.

\section{Occupation}

Among non-users, farmers were the biggest group consisting of three in the North and three in the South. Their main jobs were cultivating rice, corn, vegetables or aquaculture. Other non-users were three folk-artists in Bacninh province, one owner of a large seafood restaurant in Hochiminh city, one director of a Quanho culture business center in Bacninh province and one student in Hochiminh city who came from the poor province of Quangtri in the Center.

Users' professions were more diversified, including student, government officer, university staff, researcher, public relations, medical doctor, guard keeper, hairdresser and a sales manager of Dongho folk printing.

\section{How ICT/Internet Non-users Obtained Information}

Almost all non-user interviewees were aware of the importance of information and knowledge to compete in the demanding contexts of work and life. However few people knew much about the actual use of ICTs, or e-government service delivery. Instead, they were using other channels to get information though not all of them were effective and useful.

In a study some years ago, the loudspeaker was identified as the major channel of information to farmers (World Bank. 2002; Smith, Toulmin and Qiang 2003). Our study suggests that the loudspeaker might lose its leading position. As depicted in Figure 2, the major channels were:

- Television and peers (people who lived, worked or studied near by) overtook loudspeakers to be the top sources of information. Nine of the 16 interviewees regarded TV and peers the main source of information. While TV provided various kinds of general information, peers supplied specific knowledge, such as job availability, working know-how or learning-related information;

- Loudspeaker systems were a channel through which the local authority announced local guidelines or government regulations to the people e.g. hygiene cleaning, farming schedule, health or vaccination time table. Three interviewees recognized the existence of loudspeakers in communes but revealed that they were not important to them. Information from loudspeaker was often deemed to be less attractive and very narrow (I28, Feb 25, 2006). Furthermore, the transmission time was very limited and often conflicted with the availability of villagers who were usually too busy, often working at a second job (I37, Mar 7, 2006);

- Newspapers and books were not read by rural non-ICT users in contrast to residents in urban areas (I27, Feb 25, 2006; I26, Feb 24, 2006; I53 Apr 7, 2006);

- Telephone: Thanks to the expansion of the public telecommunications infrastructure recently, more households possessed telephone set, mainly fixed phone. Seven interviewees reported that they could use telephone to exchange information about market or job with their peers;

- Radio: Four interviewees claimed radio as a source of information but two of them (I27, Feb 25, 2006 and I37, Mar 7, 2006) added that they spent very little time to listening to radio;

- Communal government and social organizations (e.g. Farmer's Associations, Women's Associations or Veterans' Associations): Social organizations sometimes organized meetings to provide villagers with information, such as know-how to raise cows or goats, or to obtain loans. Only three out of 16 persons regarded communal government or social organizations meetings as sources of information them but said they did not attend because either they did not have time (I37, 
Mar 7, 2006 and I51, Apr 7, 2006) or the information provided was not relevant or beneficial (I51, Apr 7, 2006);

- Computer and the Internet: To all non-users those technologies were something far away. One interviewee did not have any idea of what benefit the new technologies offer (I37, Mar 7, 2006).

- Communal Post and Cultural Points (CPCPs): According to Vietnam Posts (Vienampost 2006), as a joint initiative between the Ministry of Posts and Telematics and the Ministry of Culture and Information, about 8,000 CPCPs with Internet and telephone connection were set up by Vietnam Posts and Telecommunication Group in a total of 9,069 communes. That initiative was an effort to enable villagers in poor and remote areas to access to ICTs. We had a small study about this channel in late 2006 and plan to discuss about it in future. It was not identified as an information source in the interviews reported here.

An important insight gained in the non-user interviews was that computer literate peers or neighbors of non-users played an important role in providing new knowledge because of geographic proximity and relevance of content for non-users. With peers, non-users can seek the most necessary information conveniently and informally; and they can check if the knowledge they receive is usable or not. From another perspective, that trend can be interpreted as a process of displacement or substitution. Some years before, general information from TV or loudspeakers might have been adequate, but now villagers need more specific and practical knowledge for working or living, and traditional one-way media such as loudspeaker systems or even broadcast television cannot keep pace.

Figure 2- Main Sources of External Information for ICT/Internet Non-Users

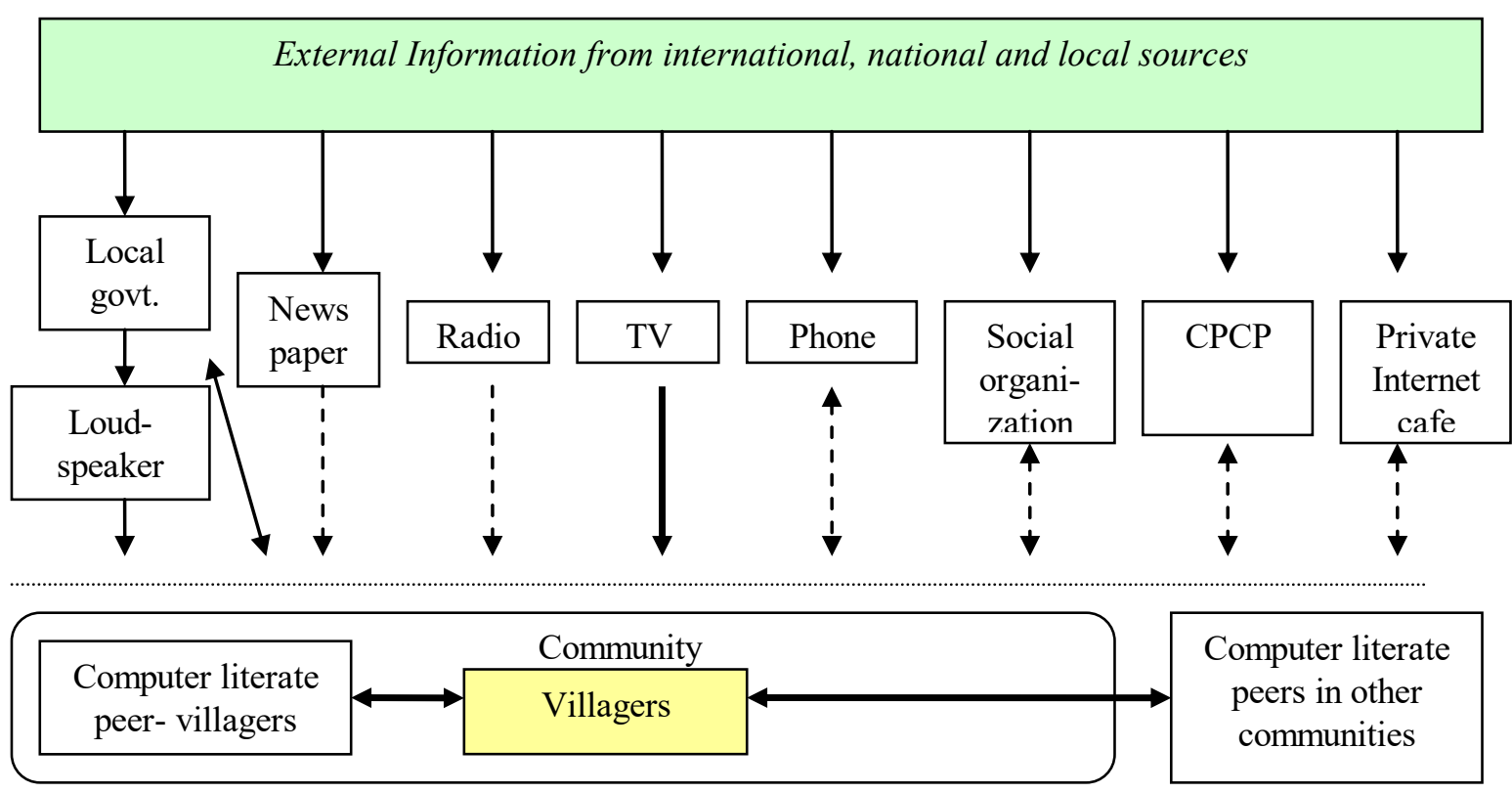




\section{Obstacles for E-government Service Delivery to ICT/Internet Non- Users}

Among the cases included in the sample, there were few rural residents who had access to the Internet, the major channel of e-government services. Even villagers who lived very close to cable networks for the Internet, TV and telephone in Bacninh or Haiphong did not use these services. Major obstacles for non-users were not identical for everyone but varied by profession, residential locality, age and economic status.

Firstly, the cost of ICTs was a forbidding barrier to farmers. In the North, the income from farming was too low, about VND 100,000 a month (US\$ 6) compared with Internet installation fee from VND 80,000 to 470,000 (I27 and I28, Feb 25, 2006, I35, Mar 7, 2006) or cable TV subscription fee at VND55,000 a month (I37, Mar 7, 2006). In the South, I51 (Apr 7, 2006) claimed that "only a rich family can afford to buy a computer at 3.5-5 million VND... Many households are very poor or live in slums."

Secondly, the gap in infrastructure availability between urban and rural areas became larger. The telecommunication infrastructure, including Internet, telephone, cable TV, quickly developed and became more available in urban areas. However in communes like Dongho in Bacninh province or Nhanbinh in Longan province, Internet service was not available. The nearest cybercafe to Nhanbinh, for example, was $7 \mathrm{~km}$ away. Students at secondary or high schools were not taught IT because there was no computer lab there (I51 Apr 7, 2006).

In regard to subjective difficulties, time constraints were often mentioned. Farmers claimed they were very busy doing a second job to get more income (I26, Feb 24, 2006, I35, Mar 7, 2006). They also stated that their educational limitations, in areas such as English and business skills, precluded them from using the Internet (I24, Feb 24, 2006). Consequently, villagers were reluctant to try using the Internet because they believed they lacked necessary skills and knowledge (I51, Apr 7, 2006). Also, farmers did not see potential benefits from the new technology. "Work at communes is often simple, do not require technology. The Internet is something far away. We do not know what benefits ICTs can bring about for us", said I35 (Mar 7, 2006).

While most older non-users would say no to ICTs, younger persons appeared more enthusiastic in approaching the Internet. Many children were observed surfing the web in Internet cafes in communes.

Though being more enthusiastic for the new technology than their elders, psychological reluctance was apparently more difficult for juniors to overcome. Shyness and timidity stopped many interviewees for the first trial of a new technology like the Internet, as 126 revealed:

The feeling of a person who never uses the Internet is very shy...Although I already know the Internet is a new channel rich of diversified information and there is an Internet cafe next door, I dare not try (I26, Feb 24, 2006).

Surprisingly, if asked to try the Internet by a peer, people could overcome that adverse feeling, as I53 recalled: "I used a computer for the first time thanks to some friends who often went to Internet cafes [who] asked me to go with them" (I53, Apr 6, 2006).

While almost all farming interviewees had no intention to use the Internet or a computer, some revealed that they might encourage their children to use ICTs in the expectation that their children could learn the emerging technology. Along these lines, I27 (Feb 25, 2006) bought a computer set for his son who studied in Hanoi. Similarly, the old artisan I21 asked his children to set up a website to market his Dongho prints via the Internet.

In summary, non-users (and especially farmers in the countryside) were visibly more disadvantaged than users in receiving e-government services. Main obstacles to them were limited education, low awareness and literacy of ICTs, low income, old age, timidity as well as lesser availability of e-government services and telecommunication network access. 


\section{Obstacles for E-government Service Delivery to Current ICT/Internet Users}

This section presents major features of and obstacles to interviewees who were currently Internet users in Vietnam, including frequency, experience, place of access, education and purpose of online activities.

\section{Online Time}

There was a clear difference in the years of experience with computers and the Internet and the usage time between rural and urban users. Users in cities had longer experience with computer sand the Internet than counterparts in the countryside (8.9 years and 5.7 years vs. 2.0 years and 2.0 years, respectively). In terms of usage hours per week, the former also used at least three time more than the latter (23.6 hours vs. 6.8 hours, respectively). Some users were computer game players who spent much more time with the Internet than general users, with a mean of 47.4 hours per week (about 7 hours per day). I08, a player in grade 12, even claimed that sometimes he played 20-22 hours a day (Jan 24, 2006). Youth may be exposed to computers and the Internet from an early age. For example, the 12 year old I33 (Mar 6, 2006) disclosed that he had exposure to a computer for three years. Some even used computers before going to primary school, as revealed by I07, a gamer in Hanoi (Jan 24, 2006). Data about the sample's Internet experience and usage time is summarised in Table 3.

Table 3 - Computer Experience and Usage Time

\begin{tabular}{lll}
\hline Indicator & Urban & Rural \\
& user & user \\
Average years of using a computer & 8.9 & 2.0 \\
Average years of using the Internet & 5.7 & 2.0 \\
Average weekly usage hours & 23.6 & 6.8 \\
Maximal weekly usage hours & 56 & 8 \\
\hline \multicolumn{1}{c}{$\mathrm{N}=20$ interviewees } & &
\end{tabular}

\section{Access Points}

Five main locations of Internet access identified in descending order of using frequency are: Internet cafes, home, office, school and peer's home. Internet cafes (other names in Vietnam: Internet shops, Internet dealer or Internet Service Center) were the most popular places where users could come to play games, chat, surf the Internet or make international VoIP calls at very low rates, about VND 2-3,000 per hour. Those places were usually full of students from nearby schools. Ninety percent of interviewees answered that they used computers in such places.

More than half of the ICT/Internet user interviewees (55\%) used home computers. This was a new phenomenon if we recall that computers had been a luxury to families just a few years before. A quarter of people $(25 \%)$ used office computers. Two teenagers $(10 \%)$ claimed that they retrieved the web from their friend's house. It was surprising and sad to realize that schools did not play much role in providing computer and Internet service to the people (only 10\%). Some schools even prohibited students from using the Internet. I22, a high school student in Ho town (Feb 20, 2006) revealed:

Many students dare not go to Internet cafes because either they don't know about IT or their teachers forbid it. My school also prohibits students from the use of the Internet because using the Internet means playing games or accessing to bad websites. My school expelled several students who went to Internet cafes.

Nobody claimed that they had accessed the Internet from CPCPs. 


\section{Usage Purposes}

To answer the question "What are the primary purposes for which you use the Internet/ ICTs?" 10 top activities were identified and none of them related to e-government services. Ninety percent of the users had at least a Yahoo email account though they did not spent much time using it. The uses of ICT listed in the most-mentioned order were: chatting, online multiplayer games, news or information, online music, downloading educational materials, solo games, work, other entertainment, creating online content, making friends and relaxing.

\section{Usage and Education}

The usage purposes were different between those who had higher education and those who had not. University students were the most diversified online users who exploited many functions of computers and the Internet such as email, chat, and multiplayer games, as well as study, online music and high rates of searching for news and information. One university student created online content as a super moderator of an online forum. High school students used less sophisticated applications such as emailing and chatting, followed by multiplayer or solo games, news and information and other activities. Many male high school students played truant from school to play games at Internet cafes. Bachelor's degree holders who were older than other groups spent less time on chat and computer games than others but more for work, study, news and information. The data for secondary school students was too sparse as only one student (I65 Dec 18, 2006) was interviewed. However, her data suggested that people with low levels of formal education used computers for entertainment or study, but in a relatively unsophisticated way.

\section{Usage and Other Factors}

Besides education, the online behaviour of users was also affected by other dimensions such as gender, experience, hobbies and living location.

Firstly, male users spent more time on chat and multiplayer games than female who most likely spent more time on searching for news and information, playing solitary games, entertainment, study and work. In searching news or information, male users looked for political, sport or lottery information while female users spent more time on social, business and IT topics, or on topics of special relevance to women or children. However, both genders were similar in regard to emailing and listening to online music. The majority of users did not chat with strangers but rather with old friends. Several male users made friends with unknowns. This finding is somewhat similar to the features of American online male and female users in 2001 (Howard, Rainie and Hones 2001).

Secondly, experience influenced the way people used ICTs. Similar to American users (Lebo, Cole, Suman, Schramm, Bel, Lunn, Maguire, Hanson, Singh and Aquino 2004), very experienced Internet users (with 5 years or more experience) spent the largest amount of time on email, instant messages, multiplayer games, more specific news, information and professional work, while new users (with 2 years or less) spent most time in emailing and chatting, followed by surfing information, offline or solo games and music.

Thirdly, people with different ages used computers differently. Elder people spent less time in chatting than younger. Social duties such as family responsibility or childcare may limit people being online. I34, a medical doctor, explained in his interview (Mar 6, 2006) why he seldom chatted: "Before marriage I chatted a lot. Now I seldom enter a chat room except when I chat with my sister overseas".

Lastly, there was a clear distinction in the complexity of usage between rural users compared with urban users. While urban residents explored diversified online activities, rural users generally used relatively simple functionalities such as email or chat. They also spent much of their time on offline games owing to the low quality of connection. This difference was a visible evidence of the social divide in the Internet age in Vietnam. 


\section{External Challenges}

Despite the increasing development of local e-newspapers and e-publications in Vietnam recently, interviewees still complained about the quality of the Vietnamese content. One interviewee remarked: "the Internet does not change much of my working practice because if I need a professional document, I have to search in foreign websites" (I34, Mar 3, 2006). Another (I07, Jan 24, 2006) pointed out: "Information in Vietnamese websites is poor and not always most updated".

In relation to infrastructure, most users (other than those in Hanoi and Hochiminh cities) complained about the poor telecommunications infrastructure. Even in a big city like Haiphong, a major harbor 100 $\mathrm{km}$ east to Hanoi, users were dissatisfied with the service. "The connection is often disrupted", said I34 (Mar 3, 2006). In rural areas, the infrastructure was even worse both in coverage and quality. A user in a rural Internet cafe in Bacninh province, $30 \mathrm{~km}$ north east to Hanoi, exclaimed "the connection in rural Internet cafe is very slow. Many times I wanted to send a message but had to cease it since it took so long" (I22, Feb 20, 2006).

The over-regulation of the Internet was a topic of criticism by many interviewees. One person (I07, Jan 24, 2006), for example, explained: "The requirement of the government for security purposes, such as showing identification card when entering an Internet shop, is neither relevant nor manageable". An owner of an Internet cafe in Haiphong shared this idea (I32, Mar 6, 2006), An article in Vietnamnet, a popular Vietnamese online newspaper made the point that no Internet café could avoid violating the Circulation No. 02/2005/TTLT-BCVT-HHTT-CA-KHDT on management of Internet dealerships. Such a regulation was not only cumbersome and unrealistic, but also restricted children under 14 from using Internet cafes (Vietnamnet 19/07/2006).

In comparison with users in developed countries, the complexity level of online applications used by Vietnamese people was clearly lower. The users interviewed spent most of their time on simple applications like email, chat and gaming. Fallows' data suggested that American users exploited the web with more sophisticated activities such as shopping and buying online, searching for health or travel information, tracking credit cards, banking or paying bills (Fallows 2004). Overcoming users' real or perceived shortfalls in skill or confidence is an important factor for achieving full effectiveness of e-government services.

\section{Users' Obstacles}

Obstacles identified in the interviews of users may be grouped into five areas: namely the English language, technological skills, personality development, economic affordability and rural disadvantage. These are discussed in turn below.

\section{The English Language}

English, the dominant Internet language, was found to be a barrier to the majority of the users. For example, an academic said "I do not know much English, especially technical terms" (I05, Jan 24, 2006). A doctor gave his reason for only reading Vietnamese websites: "It is essential to know English to read professional documents on the Net. Therefore, I only enter Vietnamese websites" (I34, Mar 3, 2006).

With the Internet, literacy takes on greater importance, as it is mostly text based (Tigre and O'Connor 2002). Language is a big factor in Internet usage (De Boer and Walbeek 1999; Palmer 2000). Salman (2004) viewed language as a key Internet content issue. Cullen (2001) noted that China and Russia only experienced significant growth in Internet usership once content was provided in Chinese and Cyrillic. 


\section{Technological Skills}

Most users had difficulty in searching for information because they did not have technical skills especially searching techniques. One user complained: "It takes much time to find necessary information if the connection is not speedy and we don't know appropriate keywords." Four users expressed concerns about Internet security, such as viruses and spam (I12, Jan 25, 2006; I05, Jan 24, 2006; I34, Mar 3, 2006; and I06, Jan 24, 2006) and one user was worried about being hacked (I48, Apr 5, 2006).

\section{Personality Development}

Three users expressed concern about possible bad effects of unhealthy Internet content on adolescents, the major users of the Internet in Vietnam. As one user explained, unhealthy content of the net, such as erotic websites or the like, may badly spoil the personality of adolescents, who:

often have limited social knowledge and experience become bewildered accessing the enormous information in the Internet, and may not adjust themselves to bad information. That can have negative impact on their personality development (I48, Apr $5,2006)$

\section{Economic Affordability}

Unlike the situation for rural users, economic affordability was seen not to be a major obstacle for urban users. The appearance of many private Internet cafes in all cities and big towns in recent years made the Internet both accessible and affordable to almost all urban users. As one interviewee put it, (I03, Jan 20, 2006) "the cost of using the Internet at cyber cafes is not a problem". However, if used too long for gaming, the cost would not be small. With the availability and affordability of Internet cafes, they could become ideal e-government service points.

\section{Rural Disadvantage}

As was expected, rural users were disadvantaged compared to their urban counterparts in many aspects of ICT usage. Rural students have more difficulty accessing the Internet than their counterparts in the city. As one user explained (I22, Feb 20, 2006) "In the Internet cafe, many [rural] students only use applications like chat or email which have already been installed by the Internet cafe manager. They don't know how to access a website or how to search for information". Rural villagers, especially farmers, lacked IT literacy simply because there was no IT training available in their region. One interviewee summed up some of the main issues:

Our IT literacy is limited. In the countryside, even if we want to learn IT, we do not have much chance. There is no IT training centre in my district but only in Hanoi and Bacninh. How can I arrange my time to study there and to work here as well as to look after my children? (I23, Feb 20, 2006).

\section{Discussion and Recommendations}

As ICT/Internet users and non-users are not identical in their needs and capacities, e-government approaches should not be the same for everyone but rather be customized to take account of the special needs of at least these two large categories of citizens. The first strategy should take into account of the 16 million online users who are mostly young, well-educated, and technically adept and agile; and the second for the 70 million non-users who are digitally marginalized. By approaching each group appropriately government can help citizens overcome the obstacles to receiving public services.

Non-users face many more difficulties than users in the possibility of receiving electronic services from the government. As identified above, social exclusion, low income, limited education, unfamiliarity and timidity, low expectations of government services, unavailability of technology, telecommunication 
costs and time constraints were serious obstacles to the adoption of e-government by these people. Thus besides considerations to assist current users suggested below, special measures could be taken to make non-users, bit by bit, familiar with electronic transactions and administration. Non-users could also be indirectly assisted from e-government services through intermediary channels additional to the Internet. As shown in Figure 2, non-users can benefit from public services or information from peers, family relatives or communal authorities who may have more opportunity or capacity to access to egovernment websites.

As a prerequisite to being a direct beneficiary of e-government services, a non-user must become a user. They need to become aware of the possible advantages of ICTs and the Internet in offering them more effective and convenient government services. In the interviews for the study, TV was identified as the most accessible and effective channel of information. Television can therefore become a prime medium for government to raise awareness about the Internet and e-government among non-users.

Timidity about the first trial of ICTs is a psychological barrier that should be seriously kept in mind by e-government implementers. Special attention is needed to young non-users who are more likely to want access to new technology. Young people should be encouraged to become familiar with the Internet and online public services. An example of this approach is a project that Vietnam Data Company (VDC) piloted using WiMax technology in Vanhoa Secondary School in Laocai in October 2006 by which ethnic minority students had the first chance to approach computers and the Internet in the mountainous region (Hung 2006). Similar activities, that help the youngsters to overcome the psychological timidity for their first attempt to use ICTs, should be encouraged in other places.

On the national scale, opportunities to gain ICT literacy could be offered in schools, ICT training centres and via TV programs so that students and as many other people as possible could gain familiarity with the technology. And most importantly, e-government projects should identify non-user needs to provide relevantly customized information and services to them. These services should meet the very concrete, practical requirements of people in each locality. Land/house registration and disputes, and reporting of governmental corruption are examples of current hot topics among that the Vietnamese public in relation to the authorities.

In the worldwide context, e-government projects such as Online Dispute Resolution, the emerging set of tools and techniques for resolving disputes online, have the potential to successfully resolve half a million disputes per year (Tyler and Bretherton 2004) - this is but one example of an area where egovernment facilitation could materially assist Vietnamese participation in global business. Unless egovernment continuously addresses new developments such as this, it could easily lose relevance in much the same way as the loud-speaker system discussed earlier.

Internet users are the direct potential customers of e-government projects. Given that the majority of them are young and well-educated, initiatives of e-government should be highly targeted towards users' interests, demands and benefits. Online public services, unless specifically satisfying young people's needs, would not make much sense to them. Looking back to the pattern of online usage discerned through the interviews, the main purposes of the online activities can be regrouped into communication, entertainment, education and job related themes. Potential e-government projects should carefully take into consideration these factors, and seek to integrate services with existing and emerging use patterns.

For instance, the government can legalize the validity of electronic application forms and allow the youth to download them from government websites rather than buying paper forms from authorities. That simple activity could save much logistical workload for government agencies as well as relieve the frustrations of red tape that such organizations impose upon the people. Vu and Jones (2006) suggested that "Before investing resources and time in new online services or initiatives provinces should ensure they have done all they can do with their current infrastructure, such as ensuring forms are available for download". Two governmental portals on education and labor are examples that illustrate this argument. 
At the moment http://moet.gov.vn, the website of the Ministry of Education and Training provides information to students, from news and legal documents to examination plans and students' scores. If students and their parents could also download training and education-related application forms such as enrolment, resume pro formas for university exam applications, and the education text books from grade 1 to 12 that are needed by all 20 million Vietnamese students, it would save much time, money and paper for all parties.

Similarly, http://www.molisa.gov.vn/, the website of the Ministry of Labor, Invalids and Social Affairs, presently provides no online job-related application forms or online forums about job opportunities and required skills. At the provincial level, departments of education and training, and departments of labor, injured war veterans and social affairs should establish or upgrade websites to provide more customized content on education, training and jobs to meet the specific demands of each locality. If these kinds of relevant, specific services were provided, the benefit - and thus the attractiveness - of sites to users would be much higher than sites providing merely general introductions or news releases quoted from other news media. E-government can start from this simple one-way provision of information before contemplating more advanced but higher cost projects.

It was a striking feature of the interviews for the study that none of the interviewees - even those with well-developed ICT skills and ready access to the Internet - had undertaken an online transaction with a government website. This suggests that more effort should be made to inform citizens about the existence of e-government websites, especially at the point when these websites are upgraded to provide relevant interactive services. Such awareness raising programs could be delivered to citizens through popular channels such as television. It is important to equip users with ICT skills such as searching egovernment services on the Internet. It is also necessary to develop a Vietnamese-language searching tool to help the users who, as shown above, have trouble in finding needed information: content in the Vietnamese language is best interrogated by a search engine customized to that language and cultural context. Jaeger and Thomson (2003) claimed that an e-government system would fail if the government did not take an active role in educating citizens about the value of e-government.

To provide e-government services to users in rural and poor areas, much more work is needed. The government may need to consider the social exclusion barrier to e-government imposed by a shortage or absence of Internet availability in rural areas - a classic manifestation of the digital divide. Farmers, especially those in the north, centre, highland and mountainous area, have very low incomes. As telecommunication and Internet connection fees are still expensive to most rural residents, policies to reduce or subsidize telecom tariffs as well as other relevant measures to encourage rural people to use the Internet are recommended. Margetts and Dunleavy (2002) suggested that incentives to encourage citizen uptake of electronic services, such as lowering the cost of transaction to a feasible level for farmers, are important to increase the adoptability of e-government. The importance of two-way channels of information, including telephony, professional associations and especially peers are extremely important to villagers and should be consistently encouraged. Local governments play a critical role in promoting those channels as well as potential Internet access points, such as CPCPs or private internet cafes. Cecchini and Raina asserted that e-government projects imperatively need the collaboration of the local staff in reducing the gap between technology and the reality of social context, and creating a sense of local ownership. "The local administrative and political actors need to be involved in the implementation of the project. Otherwise, the likelihood of failure increases dramatically" (Cecchini and Raina 2004).

Finally, to enhance the availability of technology including the presence of telecommunication networks in communes, the existence of Internet access points is essential to make information accessible to the people. For that purpose, the role of Internet cafes with their widespread presence and cheap pricing should be taken into consideration in e-government strategy and programs. Clusters of e-government projects + governmental authorities + CPCPs + Internet cafes are prominent potential channels in providing government services to citizens. Within such an approach, Internet cafes with their wide market coverage in the country, may feature locally relevant government websites, with some simple guidelines for users. 


\section{Conclusion}

Vietnam is transforming into a networked society where more people are becoming connected and more advanced applications, such as e-government, are becoming available. Compared to young, dynamic and well educated ICT/Internet users, non-users are significantly disadvantaged in accessing egovernment services. ICT/Internet non-users still vastly outnumber users in Vietnam. This paper has argued that in order to provide effective e-government to all citizens, the great majority of people need to become ICT users. People need to become acquainted with computers and build their IT literacy. It has also been suggested that for poor and disadvantaged areas and for farmers, special measures beyond the present simple CPCPs should be taken. People should be given a better chance to use the Internet by clustering private Internet cafes and public CPCPs as access nodes where government websites with relevant content, and e-government services that hopefully will become increasing interactive, can be accessed.

To become direct beneficiaries of e-government, people must first have a basic level of ICT access and literacy. The data from the interviews shed light on current barriers to attaining this level of egovernment readiness from the demand side. It was found that the computer experience, education level, age, gender and the availability of ICTs infrastructure all influence the likelihood of ICTs, and thus egovernment, adoption by citizens. Further obstacles to non-users are financial affordability, infrastructure unavailability, educational and psychological constraints. As antecedents to egovernment, all these obstacles need to be overcome.

Inevitably the aspiration to deliver excellent, responsive e-government services to the great majority of citizens has extensive antecedent implications for the workings of government as a whole. E-government services, if they are to succeed, cannot simply be "wallpapered" on to systems and structures of public administration that are inefficient, slow and inward looking. The drive towards effective e-government service delivery needs to be accompanied by a re-examination of government processes, especially in terms of their responsiveness to citizens' needs. A key factor is the capacity of each government officer to deal creatively with the new electronic administration environment. The transformation towards a citizen-centric, ICT enabled, government service regime is a complex challenge, requiring extensive practical action, as well as ongoing research and evaluation. However the potential economic and cultural payoffs for individuals and the nation could be immense as improved communication between citizens and government results in a more informed and empowered society. 


\section{References}

ADB (2005, December 1). “ADB Loan to Boost Viet Nam’s Poverty Reduction Program.” Retrieved April 17, 2007, from http://www.adb.org/media/Articles/2005/8914_Viet_Nam_poverty_reduction/.

Baker, C., P. Tumbarello, et al (2006). Vietnam: Statistical Appendix. Washington, D.C., International Monetary Fund: 51.

Bhatnagar, S. C. (2004). E-government : from vision to implementation : a practical guide with case studies. New Delhi, Sage Publications.

Cecchini, S. and M. Raina (2004). "Electronic Government and the Rural Poor: the Case of Gyandoot." Information Technology and International Development 2(2): 65-75.

Central Intelligence Agency (2007). World Fact Book. Washington D.C., Potomac Books.

Dapice, D. O. and S. Fellow (2003). "Vietnam's Economy: Success Story or Weird Dualism? A SWOT Analysis." Retrieved April 17, 2007, from http://ase.tufts.edu/econ/papers/200315.pdf.

De Boer, S. J. and M. M. Walbeek (1999). "Information technology in developing countries: a study to guide policy formulation." International Journal of Information Management 19(3): 207-218.

Dutta, S. and A. Jain. (2004). “The Networked Readiness Index 2003-2004.” Retrieved September 27, 2004, from http://www.weforum.org/pdf/Gcr/GITR_2003_2004/Framework_Chapter.pdf.

EIU (2006). "The 2006 e-readiness rankings.” Retrieved July 1, 2006, from www.eiu.com/2006eReadinessRankings.

Fallows, D. (2004). “ The Internet and Daily Life: Many Americans use the Internet in everyday activities, but traditional offline habits still dominate.” Retrieved July 1, 2006, from http://www.pewinternet.org/pdfs/PIP_Internet_and_Daily_Life.pdf.

General Statistics Office of Vietnam (2006). "Average population by sex and by residence." November 15 , 2006, from http://www.gso.gov.vn/default_en.aspx?tabid=467\&idmid=3\&ItemID=4704.

General Statistics Office of Vietnam (2006). "Number of administrative units as of 31 December 2005 by province." November 15, 2006, from http://www.gso.gov.vn/default_en.aspx?tabid=466\&idmid=3\&ItemID=4653.

Hochiminh Computer Association (2006). "Toan Canh CNTT Vietnam 2006 [Vietnam ICT Outlook 2006]." Retrieved July 28, 2006, from www.hca.org.vn/tin_tuc/hd_hoi/nam2006/thang7/vio2006/baocaotoancanh_2006.pdf

Howard, P., L. Rainie, et al (2001). Days and nights on the Internet: The impact of a diffusing technology. The Internet in everyday life. B. Wellman and C. Haythorthwaite. Oxford, Blackwell: 45-73.

Hung, H. (2006, October 31). "Thử nghiệm WiMax không đơn thuần là công nghệ [WiMax test is not simply technology].” VnExpress Retrieved March 1, 2007, from http://vnexpress net/Vietnam/Vitinh/2006/10/3B9EFDD4/.

Intel and Gov3 (2006). "Solutions White Paper: Citizen centric government - Global Best Practice in Delivering Agile Public Services to Citizens and Businesses.” Retrieved January 15, 2007, from http://www.intel.com/business/bss/industry/government/citizen_wp.pdf.

ITU (2006). “ICT Statistics.” Retrieved August 29, 2006, from http://www.itu.int/ITU-D/ict/statistics/.

Khổng, D. (2002). Một số vấn đề dân số với phát triển các dân tộc thiểu số và miền núi Việt Nam [Some issues on population and developement of ethnic minorities in mountains of Vietnam]. Phát triển bền vững miền núi Việt Nam, 10 năm nhìn lại và những vấn đề đặt ra [Sustainable development in mountainous areas of Vietnam: 10 years review and considerations]. Hanoi, Agricultural Publishing.

Lebo, H., J. I. Cole, et al (2004). "The UCLA Internet Report: Surveying the digital future, year four: Ten years, ten trends." Retrieved July 4, 2006, from http://www.digitalcenter.org/downloads/DigitalFutureReport-Year4-2004.pdf.

Marche, S. and J. D. McNiven (2003). "E-government and E-governance: the future isn't what it used to be." Canadian Journal of Administrative Science 20(1): 74-86.

Margetts, H. and P. Dunleavy. (2002). “Cultural barriers to e-government.” Retrieved May 22, 2007, from http://www.governmentontheweb.org/downloads/papers/Cultural_Barriers.pdf.

Martin, B. and J. Byrne (2003). "Implementing e-Government: widening the lens.” Electronic Journal of eGovernment 1(1).

Nguyen, H. (2007). “Sẽ kế thừa những kết quả của Đề án 112 [Inherit the 112 Project].” Retrieved May 23, 2007, from http://vnexpress.net/Vietnam/Vi-tinh/2007/05/3B9F5E20/.

Nguyen, T. T. (2001). Tổng quan về chính phủ điện tử [Overview of electronic government]. Tin học hoá quản lý nhà nước ở Việt Nam và mô hình chính phủ điện tử [Computerization of state administration in Vietnam and the electronic government model]. M. G. Doan and C. H. Nguyen. Hanoi Office of Government, Defense Publishing House: 1-19. 
Oliver, E. L. and L. Sanders, Eds. (2004). E-government reconsidered : renewal of governance for the knowledge age. Sipp/Ipips ; 3. Regina, Sask., University of Regina Saskatchewan Institute of Public Policy.

Palmer, J. J. (2000). "Internet access in Bahrain: business patterns and problems." Technovation 20(8): 451458.

Pham, T. B. H. (2005). Vietnam E-Government Overview: A Survey of Government Websites. Vietnam IT Overview 2005. H. C. Association. Hochiminh, Hochiminh City Computer Association.

Smith, P., L. Toulmin, et al (2003). "In-Focus: ICT in Vietnam - Accelerating ICT Development in Vietnam." I-Ways, Digest of Electronic Commerce Policy and Regulation 26 31-40.

Tigre, P. B. and D. O’Connor. (2002). "Policies and Institutions for E-Commerce Readiness: What Can Developing Countries Learn from OECD Experience?” Technical Papers No. 189 Retrieved January, 2005, from http://www.oecd.org/pdf/M00028000/M00028358.pdf.

Tran, C. N. (2005). Impact of Policy on Development of E-Commerce in Vietnam E-commerce in the Asian context: selected case studies. R. Lafond and C. Sinha. Singapore, Institute of Southeast Asian Studies \& International Development Research Centre: 70-94.

Tyler, M. C. and D. Bretherton (2004). Lessons for eGovernment: Online Dispute Resolution. the Australian Electronic Governance Conference 2004, Melbourne, University of Melbourne - Department of Political Science.

Vienampost (2006). "Điểm bưu điện văn hoá xã: một điểm sáng ở nông thôn [Communal Post and Cultural Center- A bright spot in countryside]." Vietnam Posts Retrieved June 11, 2006, from $\mathrm{http}$ //vietnamgateway.org/vanhoaxa/dbdvhx.php?action=thongtin\&chuyenmuc=0901\&id=060103160035.

Vietnam Internet Center (2007). "Thong bao so lieu phat trien Internet Vietnam 5/2007 [Statistic data of Internet growth in Vietnam by April 2007].” Retrieved May 31, 2007, from http://www.thongkeinternet.vn/jsp/trangchu/index.jsp.

Vietnamnet (2006, July 19). "Đại lý Internet công cộng:không vi phạm mới lạ [Public Interne dealer: how can not violate]." Vietnamnet Retrieved May 1, 2007, from http:/www.vietnamnet.vn/cntt/206/07/592721.

Vu, K. M. and R. Jones. (2006). "VNCI Policy paper \#7: E-Government and Business Competitiveness: a Policy Review." Retrieved November 1, 2006, from http://www.vnci.org/default.asp?act=Download\&downloadID $=57$.

Williamson, K. (2002). Research techniques: sampling. Research methods for students, academics and professionals: information management and systems. K. Williamson and A. Bow. Wagga Wagga, NSW, Centre for Information Studies, Charles Sturt University: 225-234.

World Bank (2003). Vietnam Development Report 2004: Poverty. Hanoi, Poverty Reduction and Economic Management Unit, East Asia and Pacific Region, the World Bank: 194.

World Bank (2002). Accelerating Information \& Communication Technologies Development in Vietnam. 
